\title{
SUPLEMENTASI TEPUNG IKAN TERPROTEKSI EKSTRAK TANIN HIJAUAN KABESAK KUNING, KABESAK HITAM DAN KIHUJAN DALAM RANSUM TERHADAP PERTUMBUHAN TERNAK KAMBING
}

\author{
Emma Dyelim Wie Lawa dan Edwin J.L. Lazarus
}

Fakultas Peternakan Universitas Nusa Cendana, Kupang-NTT

\begin{abstract}
ABSTRAK
Penelitian ini bertujuan mempelajari pengaruh suplementasi protein tepung ikan terproteksi ekstrak tannin hijauan kabesak kuning, kabesak hitam dan kihujan dalam ransum terhadap pertumbuhan ternak kambing. Penelitian ini dirancang dalam Rancangan Acak Lengkap dengan empat perlakuan yang diulang empat kali. Sebanyak enam belas ekor ternak kambing lokal dialokasikan untuk menerima perlakuan P0 (pemberian ransum basal + jagung-urea + tepung ikan tidak terproteksi ekstrak tanin), P1 (pemberian ransum basal + jagung-urea + tepung ikan terproteksi ekstrak tanin kabesak kuning), P2 (pemberian pakan basal jagungurea + tepung ikan terproteksi ekstrak tanin kabesak hitam) dan P3 (pemberian pakan basal + jagung-urea + tepung ikan terproteksi ekstrak tanin kihujan). Ransum basal yang diberikan terdiri dari kombinasi rumput alam dengan lamtoro (60:40). Hasil penelitian menunjukkan bahwa perlakuan yang diterapkan mempengaruhi pertumbuhan ternak kambing dan pertumbuhan terbaik ditunjukkan ternak kambing yang mendapat suplemen tepung ikan terproteksi ekstrak tannin kabesak kuning (KBK 719,88 g/e/h; Retensi N 10,46 g/e/h; PBB 52,94 g/e/h dan EPR 0,070) dan yang mendapat suplemen tepung ikan terproteksi ekstrak tannin kabesak hitam (KBK 719,88 g/e/h; Retensi N $10,03 \mathrm{~g} / \mathrm{e} / \mathrm{h} ;$ PBB $51,47 \mathrm{~g} / \mathrm{e} / \mathrm{h} ;$ dan EPR $0,072)$.
\end{abstract}

Kata Kunci : Suplementasi, tepung ikan, proteksi, ekstrak tannin, pertumbuhan kambing

\begin{abstract}
SUPPLEMENTATION OF FISH

MEAL PROTECTED OF TANNIN EXTRACT FROM ACACIA LEUCOPHLOEA, ACACIA CATECHU AND SAMANEA SAMAN IN RATION ON GOAT PERFORMANCE. The objective of research was to study supplementation of fish meal protected of tannin extract from Acacia leucophloea, Acacia catechu and Samanea saman in ration on goat performance. The experiment was arranged in Completely Randomized Design with 4 treatments and 4 replicates. Sixteen male local goats were allocated for treatments: P0 (basal feed + corn-urea + non protected fish meal with extract tannin), P1 (basal feed + corn-urea + protected fish meal with extract tannin from Acacia leucophloea), P2 (basal feed + cornurea + protected fish meal with extract tannin from Acacia catechu), and P3 (basal feed + corn-urea + protected fish meal with extract tannin from Samanea saman). Combination native grass with Leucaena used as basal feed (60:40). The result of experiment showed that the treatments effective in increasing goat performance and the best treatment were supplementation fish meal with extract tannin from Acacia leucophloea (DMI 719,88 g/h/d; $\mathrm{N}$ retention $10,46 \mathrm{~g} / \mathrm{h} / \mathrm{d}$; daily gain 52,94 $\mathrm{g} / \mathrm{h} / \mathrm{d}$ and ration efficiency 0,070 ) and Acacia catechu (DMI 719,88 g/h/d; N retention 10,03 ; daily gain $51,47 \mathrm{~g} / \mathrm{h} / \mathrm{d}$ and ration efficiency 0,072).
\end{abstract}

Keywords : supplementation, fish meal, protection, tannin extract, goat performance 


\section{PENDAHULUAN}

Ternak ruminansia, termasuk ternak kambing memiliki karakteristik yang unik dalam segi pencernaannya. Setiap bahan makanan yang dikonsumsi ternak kambing tidak semuanya langsung masuk ke dalam lambung sederhana, umumnya bahan makanan tersebut mengalami proses pencernaan dalam rumen oleh mikroorganisme yang ada di dalamnya. Menurut Saricicek (2000), ternak ruminansia dengan tingkat produksi yang tinggi membutuhkan nutrien, khususnya protein dalam jumlah yang banyak. Produk hasil degradasi protein umumnya berlebihan dan terbesar terbuang karena protein ransum yang didegradasi dan asam amino esensialnya akan dideaminase. Jadi penguraian protein bahan makanan menjadi tidak efisien dari segi kebutuhan tubuh ternak, misalnya protein bermutu tinggi yang terdapat dalam pakan konsentrat seperti tepung ikan akan mengalami penguraian yang merugikan jika didegradasi dalam rumen. Menurut Mahadevan, et al. (1980), tepung ikan mengalami degradasi dalam rumen sebesar 31 persen, sementara menurut Miller (1973), nilai degradasi tepung ikan dalam rumen berkisar $30-70$ persen tergantung pada prosesing yang dilakukan. Untuk itu diperlukan upaya untuk melewatkan protein asal tepung ikan ini langsung ke dalam saluran pencernaan bagian belakang yaitu abomasum, agar dapat dicerna oleh ensim pencernaan yang ada dalam lambung tersebut.

Upaya melewatkan protein bahan makanan dari serangan mikroorganisme dalam rumen bertujuan melindungi protein bahan makanan agar tidak didegradasi oleh mikroorganisme dalam rumen dan akhirnya dapat tersedia dalam jumlah dan kualitas yang baik bagi enzim pencernaan dalam abomasum. Tanin kondensasi yang terdapat dalam hijauan leguminosa dapat menonaktifkan ensimensim yang dihasilkan oleh mikroba rumen. Tanin mengikat protein dengan ikatan hidrogen yang sensitif terhadap perubahan $\mathrm{pH}$. Tanin kondensasi akan berikatan stabil pada $\mathrm{pH} 4-7$ di dalam rumen, sedangkan pada $\mathrm{pH}$ yang ekstrim (pH kurang dari 3) di abomasum tannin akan terlepas dan menjadi tersedia bagi ternak (El-Wazyri et al., 2005). Penelitian ini dilakukan untuk menguji sampai sejauhmana suplementasi tepung ikan yang diproteksi ekstrak tanin dari hijauan kabesak kuning (Acacia leucophloea), 
kabesak hitam (Acacia catechu) dan kihujan (Samanea saman) dapat meningkatkan pertumbuhan ternak kambing lokal.

\section{MATERI DAN METODE PENELITIAN}

Sebanyak 16 (enam belas) ekor ternak kambing lokal jantan, umur pertumbuhan digunakan sebagai ternak percobaan. Ternak kambing percobaan dialokasikan untuk mendapat ransum dengan formulasi ransum yang terdiri dari pakan basal rumput alam dan hijauan lamtoro dengan perbandingan 60:40. Pakan suplemen yang terdiri dari tepung ikan $2 \%$ dan tepung jagung $3 \%$ dan urea sebanyak $1 \%$ dari jumlah tepung jagung jagung-urea. Persentase pemberian pakan suplemen didasarkan pada konsumsi pakan basal selama masa prelimineri.
Ekstrak tanin dari daun kabesak kuning (Acacia leucophloea), kabesak hitam (Acacia catechu) dan kihujan (Samanea saman) sebanyak $2 \%$ dari jumlah tepung ikan digunakan sebagai pelindung protein tepung ikan. Pakan basal rumput alam dan lamtoro diberikan secara ad libitum. Komposisi kimia bahan pakan penelitian tercantum dalam Tabel 1.

Rancangan percobaan yang digunakan adalah rancangan acak lengkap dengan 4 perlakuan dan 4 ekor ternak kambing lokal sebagai ulangan. Formulasi perlakuan ransum diatur sebagai berikut :

$$
\begin{aligned}
\mathrm{P} 0= & \text { Ternak kambing diberikan pakan } \\
& \text { basal }+ \text { jagung-urea }+ \text { tepung ikan } \\
& \text { tanpa ekstrak tanin } \\
\mathrm{P} 1= & \text { Ternak kambing diberikan pakan } \\
& \text { basal }+ \text { jagung-urea }+ \text { tepung ikan } \\
& \text { dengan ekstrak tanin kabesak } \\
& \text { kuning }
\end{aligned}
$$

Tabel 1. Komposisi Kimia Bahan Pakan Penelitian

\begin{tabular}{lccccc}
\hline Zat Makanan (\%) & \multicolumn{5}{c}{ Bahan Pakan } \\
\cline { 2 - 6 } & $\begin{array}{c}\text { Rumput } \\
\text { alam }\end{array}$ & Lamtoro & $\begin{array}{c}\text { Tepung } \\
\text { ikan }\end{array}$ & Tepung jagung & Urea \\
\hline Bahan kering & 28,09 & 26,34 & 87,73 & 87,72 & 100 \\
\hline Protein kasar & 5,12 & 24,37 & 52,31 & 7,95 & 287,5 \\
\hline Serat kasar & 28,06 & 7,09 & 0,92 & 3,64 & - \\
\hline Lemak kasar & 2,01 & 3,47 & 6,18 & 2,10 & - \\
\hline BETN & 60,22 & 55,36 & 35,87 & 69,01 & - \\
\hline
\end{tabular}

Keterangan : Hasil analisis Laboratorium Kimia Pakan, Fapet Undana. 
$\mathrm{P} 2=$ Ternak kambing diberikan pakan basal + jagung-urea + tepung ikan dengan ekstrak tanin kabesak hitam

$\mathrm{P} 3=$ Ternak kambing diberikan pakan basal + jagung-urea + tepung ikan dengan ekstrak tanin Kihujan

Parameter yang diukur untuk mengetahui respon ternak terhadap perlakuan yang diberikan adalah,

1. Konsumsi bahan kering ransum

2. Kecernaan bahan kering dan zat makanan ransum

3. Neraca nitrogen ransum

4. Total zat makanan tercerna (TDN)

5. Pertambahan berat badan

6. Efisiensi penggunaan ransum

Data hasil penelitian ditabulasi kemudian dianalisis menggunakan sidik ragam sesuai rancangan percobaan yang digunakan. Uji sidik ragam akan menentukan ada atau tidaknya pengaruh perlakuan terhadap parameter yang diukur. Pengaruh perlakuan yang terjadi ditindaklanjuti dengan uji jarak berganda Duncan untuk mendapatkan perbedaan sekaligus menentukan perlakuan terbaik yang diperoleh. Analisis data ini mengacu pada prosedur yang ditunjukkan Steel dan Torrie (1991).
HASIL DAN PEMBAHASAN

\section{Konsumsi, Kecernaan Bahan Kering dan Zat Makanan Ransum, Retensi Nitrogen dan Total Digestible Nutrient (TDN) Ransum}

Rata-rata konsumsi bahan kering ransum dari ternak kambing penelitian tertera dalam Tabel 2. Kisaran rata-rata konsumsi bahan kering ransum ternak kambing dalam penelitian ini adalah $706,67 \mathrm{~g} / \mathrm{e} / \mathrm{h}-756,58 \mathrm{~g} / \mathrm{e} / \mathrm{h}$ dan rata-rata konsumsi bahan kering ransum untuk ternak kambing penelitian seluruhnya sebesar 723,05 g/e/h. Dikaitkan dengan rata-rata berat badan ternak kambing setelah selesai penelitian yaitu $22,8 \mathrm{~kg}$, maka rata-rata konsumsi bahan kering ransum dari ternak kambing penelitian sebesar 3,17\% dari berat badan ternak kambing penelitian. Angka konsumsi bahan kering ransum ini berada di atas kebutuhan ternak kambing pada umumnya (2 - $3 \%$ dari berat badan). Gambaran ini menunjukkan bahwa penerapan perlakuan berdampak terhadap konsumsi bahan kering ransum, dimana seluruh ternak kambing yang diteliti dapat merespon ransum perlakuan dengan baik. Penggunaan kombinasi imbangan pakan hijauan rumput $60 \%$ dan lamtoro $40 \%$ disertai pakan konsentrat memberikan stimulus yang baik bagi 
penerimaan pakan dalam rumen dan berbagai aktivitas di dalamnya memacu pemanfaatan ransum secara total. Menurut Doyle (1990), hijauan dari jenis leguminosa dapat menyediakan substrat dan nutrien spesifik seperti protein murni, dinding sel yang mudah difermentasi dan mineral serta vitamin esensial bagi ternak. Penggunaan lamtoro bersama hijauan rumput sebagai pakan basal juga bermanfaat dalam mendukung pemanfaatan pakan perlakuan. Menurut Yates (1983), lamtoro dapat menjamin kecukupan natrium (Na) dalam ransum, mengontrol pemanfaatan mineral sulfur dalam ransum dan sebagai pakan kombinasi yang baik bagi hijauan lain yang berkualitas rendah.

Hasil uji statistik menunjukkan, perlakuan suplementasi tepung ikan terproteksi ekstrak tanin ketiga hijauan pohon ini dalam ransum ternak kambing penelitian tidak nyata $(\mathrm{P}>0,05)$ mempengaruhi konsumsi bahan kering ransum. Fenomena ini menggambarkan bahwa penggunaan ekstrak tanin kabesak kuning, kabesak hitam dan kihujan sebagi pelindung protein tepung ikan dalam ransum penelitian tidak berdampak pada konsumsi bahan kering ransum ternak kambing.

Tabel 2. Rata-rata Konsumsi, Kecernaan Bahan Kering dan Zat Makanan Ransum, Retensi Nitrogen dan Total Digestible Nutrient (TDN) Ransum Ternak Kambing Penelitian

\begin{tabular}{lcccc}
\hline Parameter yang Diukur & \multicolumn{4}{c}{ Perlakuan } \\
\cline { 2 - 5 } & P0 & P1 & P2 & P3 \\
\hline $\begin{array}{l}\text { Konsumsi Bahan Kering Ransum } \\
\text { (g/e/h), }\end{array}$ & 706,67 & 756,58 & 719,88 & 708,77 \\
\hline Kecernaan Ransum (\%), & & & & \\
$\quad$ - Kecernaan Bahan Kering & $78,83^{\mathrm{a}}$ & $83,75^{\mathrm{b}}$ & $82,04^{\mathrm{b}}$ & $78,08^{\mathrm{a}}$ \\
- Kecernaan Protein Kasar & $75,72^{\mathrm{a}}$ & $83,00^{\mathrm{b}}$ & $81,26^{\mathrm{b}}$ & $79,11^{\mathrm{a}}$ \\
$\quad-\quad$ Kecernaan Serat Kasar & $70,37^{\mathrm{a}}$ & $80,55^{\mathrm{b}}$ & $78,53^{\mathrm{b}}$ & $75,54^{\mathrm{ab}}$ \\
$\quad$ Kecernaan Lemak Kasar & 54,12 & 61,49 & 56,33 & 54,42 \\
$\quad$ - Kecernaan BETN & 65,33 & 74,40 & 70,28 & 68,94 \\
\hline Retensi Nitrogen (g/e/h) & $8,49^{\mathrm{a}}$ & $10,46^{\mathrm{b}}$ & $10,03^{\mathrm{b}}$ & $9,77^{\mathrm{b}}$ \\
\hline TDN Ransum (\%) & $71,43^{\mathrm{a}}$ & $81,68^{\mathrm{b}}$ & $77,69^{\mathrm{b}}$ & $75,90^{\mathrm{ab}}$
\end{tabular}

Keterangan: Superskrip yang berbeda diantara perlakuan pada setiap parameter menunjukkan terdapat perbedaan yang nyata $(\mathrm{P}<0,05)$. 
Menurut Hagerman and Robbins (1993), salah satu sifat tanin yang dapat menghambat konsumsi pakan jika senyawa ini berada dalam ransum adalah kemampuannya berikatan dengan protein pakan sehingga membentuk kompleks yang tidak larut dalam air, menyebabkan kekeruhan, pengendapan dan menghambat aktivitas ensim.

Dalam penelitian ini, diduga ekstrak tanin yang digunakan konsentrasinya dalam ransum tidak terlalu tinggi sehingga palatabilitas ransum tetap terjaga dimana konsumsi bahan kering ransum tetap tidak terpengaruh. Bate-Smith menyatakan bahwa, keberadaan tanin dalam ransum umumnya dapat merusak palatabilitas apabila kandungannya cukup tinggi karena dapat bersifat membuat rasa sepat (astringent property) atau kondisi kering dalam mulut yang berakibat pada kemampuan berikatan dengan protein saliva dan membrane mukosa di mulut selama mastikasi ransum (Aletor, 1993).

Kecernaan bahan kering ransum dari ternak kambing penelitian menunjukkan makin meningkat dengan adanya perlakuan proteksi terhadap suplemen tepung ikan dalam ransum. Adanya kecenderungan tersebut karena, walaupun di dalam rumen tepung ikan terproteksi, namun sesampai di abomasum dan usus halus protein tepung ikan menjadi tersedia bagi ternak kambing. Akibat penerimaan protein tepung ikan dalam abomasum dan usus halus tersebut, ternak menjadi terstimulus untuk mencerna pakan lebih efisien lagi. Kecernaan bahan kering ransum dalam penelitian ini cukup tinggi, berkisar dari $78,08 \%-83,75 \%$ dengan rata-rata $80,68 \%$.

Hasil uji statistik menunjukkan, perlakuan berpengaruh sangat nyata $(\mathrm{P}<$ 0,01) terhadap kecernaan bahan kering ransum. Penggunaan ekstrak tanin ketiga hijauan pohon tersebut tidak menekan kecernaan secara keseluruhan tetapi diduga penggunaannya masih dalam tingkat yang aman bagi ternak, bahkan justru meningkatkan kemampuan mencerna ternak terhadap pakan dan mikroba dalam rumen juga terkonsentrasi pada mencerna pakan basal yang tidak terproteksi. Pada dasarnya kecernaan protein kasar ransum ini adalah akumulasi dari kecernaan dalam rumen dan dalam saluran pencernaan bagian belakang ternak kambing.

Penggunaan ekstrak tanin hijauan kabesak kuning (P1) dan kabesak hitam (P2) sebagai pelindung protein tepung ikan dalam ransum nyata lebih tinggi efeknya terhadap kecernaan bahan kering ransum dibanding penggunaan ekstrak 
tanin hijauan kihujan dan yang tidak dilindungi tanin (P0). Hasil penelitian ini tidak berbeda jauh dengan hasil uji in vitro pada penelitian yang dilakukan peneliti sebelumnya (Wie Lawa dan Lazarus, 2009), dimana kecernaan bahan kering tepung ikan dilindungi ekstrak tanin kabesak kuning tidak jauh berbeda dengan tepung ikan yang dilindungi ekstrak tanin kihujan $(66,39 \%$ Vs $68,70 \%)$. Dalam penelitian terdahulu juga diperoleh bahwa kecernaan bahan kering in vitro dari tepung ikan yang dilindungi ekstrak tanin kabesak hitam nyata lebih tinggi dibanding yang dilindungi ekstrak tanin kabesak kuning. Banyak protein tepung ikan diduga lolos degradabilitas dalam rumen dan menjadi tersedia dalam saluran pencernaan bagian belakang. Senyawa tanin dari hijauan pohon akan terlepas ikatannya dengan protein tepung ikan akibat $\mathrm{pH}$ yang rendah dalam abomasum dan selanjutnya dicerna oleh ensim pencernaan, seperti yang dikemukakan Hagerman et al. (1992). Dampak negatif tidak terlihat dengan penerapan penggunaan senyawa tanin ketiga hijauan dalam penelitian ini. Diduga level tanin yang digunakan masih dapat ditolerir dalam saluran pencernaan ternak kambing. Menurut Hagerman and Robbins (1993), mamalia yang mengkonsumsi pakan dengan kandungan tanin cukup tinggi dapat mengakibatkan penurunan dalam kecernaan bahan kering dan protein kasar ransum, bahkan kenaikan berat badannya juga menurun. Kecernaan protein kasar dan serat kasar ransum ternak kambing dengan penggunaan ekstrak tanin kabesak kuning dan kabesak hitam nyata lebih tinggi $(\mathrm{P}<$ 0,05) dibanding perlakuan kontrol (P0). Penggunaan ekstrak tanin hijauan samanea saman belum memberikan efek yang menguntungkan dalam kecernaan protein dan serat kasar ransum ternak kambing pada level 2\%, ini tampak dari tidak berbedanya perlakuan ini dengan perlakuan kontrol. Kecernaan lemak kasar dan BETN tidak dipengaruhi oleh perlakuan penggunaan ekstrak tanin ketiga hijauan dimana hasilnya tidak berbeda jauh dengan tepung ikan yang tidak dilindungi ekstrak tanin.

Retensi nitrogen dalam tubuh ternak kambing nyata $(\mathrm{P}<0,05)$ dipengaruhi perlakuan perlindungan ekstrak tanin ketiga hijauan terhadap tepung ikan dalam ransum. Barry and Manley (1984) melalui perbandingan nilai prediksi pada ransum yang mengandung tanin dan yang tidak mengandung tanin, melaporkan terdapat efek positip terhadap retensi nitrogen pada domba yang diberikan Lotus corniculatus (<50 g CT/kg BK). Hal yang sama dilaporkan oleh Driedger and Hortfield (1972) bahwa terjadi 
peningkatan dalam retensi nitrogen pada domba yang diberikan bungkil kedelai yang dilindungi tanin. Perlindungan tepung ikan dengan ekstrak tanin ketiga hijauan ini nyata lebih tinggi dibanding tepung ikan yang tidak mengalami perlindungan dengan ekstrak tanin. Gambaran ini menunjukkan bahwa nitrogen dalam ransum akan mengalami deposit yang menguntungkan bagi pertumbuhan ternak kambing jika proteinnya dilindungi dari degradasi dalam rumen. Efek tanin dari ketiga hijauan dalam melindungi protein tepung ikan dalam ransum tidak berbeda terhadap retensi nitrogen pada ternak kambing. Menurut Deaville et al. (2010), apabila tanin kondensasi mengikat banyak protein dalam rumen akibatnya banyak protein mengalir ke dalam usus halus dan degradasi protein dalam rumen terhindari dan dapat digunakan untuk kebutuhan fisiologis seperti pertumbuhan.

Nilai TDN ransum ternak kambing juga dipengaruhi oleh perlakuan perlindungan ekstrak tanin ketiga hijauan dalam rumen terhadap tepung ikan. Lolosnya protein ke abomasum dan usus halus, banyak zat makanan secara total tersedia bagi ternak kambing sehingga nilai TDNnya meningkat. TDN menggambarkan nilai energi yang dicapai ternak dari pakan yang dikonsumsi untuk pertumbuhannya.

\section{Pertambahan Berat Badan dan Efisiensi Penggunaan Ransum}

Pertambahan berat badan ternak kambing akibat perlakuan perlindungan tepung ikan sebagai suplemen dalam ransum dengan ekstrak tanin hijauan kabesak kuning, kabesak hitam dan kihujan, sangat nyata $(\mathrm{P}<0,01)$ pengaruhnya. Dampak lolosnya protein tepung ikan dari degradasi rumen mengakibatkan banyak protein yang tersedia di abomasum dan usus halus untuk dicerna dan dimanfaatkan sebagai asam amino untuk memenuhi kebutuhan ternak kambing dalam menunjang pertumbuhannya. Meningkatnya pertambahan berat badan ternak kambing ini juga sudah digambarkan oleh Henson et al. (1997) bahwa untuk ternak dengan tingkat produksi yang tinggi tidak akan mampu untuk memenuhi kebutuhan asam amino dengan hanya mengandalkan protein asal mikroba saja; dan strategi peningkatan pemanfaatan protein dalam ransum antara lain mengoptimalkan ransum, menyeimbangkan komposisi asam amino ransum dan meningkatkan protein yang lolos dari degradasi rumen (Huhtanen and Hristov, 2009). Data pertambahan berat badan dan efisiensi penggunaan ransum dari ternak kambing penelitian tertera dalam Tabel 3. 
Tabel 3. Rata-rata Pertambahan Berat Badan dan Efisiensi Penggunaan Ransum Ternak Kambing Akibat Perlindungan Protein Tepung Ikan dalam Ransum

\begin{tabular}{lcccc}
\hline \multirow{2}{*}{\multicolumn{1}{c}{ Parameter yang Diukur }} & \multicolumn{4}{c}{ Perlakuan } \\
\cline { 2 - 5 } & P0 & P1 & P2 & P3 \\
\hline Berat Badan Awal (kg) & 18,00 & 18,50 & 18,75 & 18,75 \\
Berat Badan Akhir (kg) & 20,875 & 23,000 & 23,625 & 22,250 \\
Pertambahan Berat Badan (g/e/h) & $33,82^{\mathrm{a}}$ & $52,94^{\mathrm{c}}$ & $51,47^{\mathrm{c}}$ & $41,18^{\mathrm{b}}$ \\
Efisiensi Penggunaan ransum & 0,048 & 0,070 & 0,072 & 0,058 \\
\hline
\end{tabular}

Keterangan: Superskrip yang berbeda diantara perlakuan pada setiap parameter menunjukkan terdapat perbedaan yang nyata $(\mathrm{P}<0,01)$.

Ternak kambing yang mendapat suplemen tepung ikan terproteksi ekstrak tanin ketiga hijauan nyata $(\mathrm{P}<0,05)$ lebih tinggi dibanding perlakuan kontrol. Ternak kambing yang mendapat perlakuan suplementasi tepung ikan yang diproteksi ekstrak tanin hijauan kabesak kuning dan kabesak hitam nyata $(\mathrm{P}<0,05)$ lebih tinggi dibanding ternak kambing yang mendapat tepung ikan diproteksi ekstrak tanin dari hijauan samanea saman maupun yang mendapat perlakuan kontrol. Senyawa tanin dalam hijauan kabesak kuning dan kabesak hitam memiliki kemampuan mengikat protein tepung ikan lebih baik dibanding tanin yang terdapat dalam hijauan samanea saman, sehingga banyak protein yang lolos untuk dicerna dan dimanfaatkan dalam organ pasca rumen. Wang et al. (1996a) mengobservasi ternak domba yang merumput pada hijauan Lotus corniculatus (kandungan tanin kondensasi $34 \mathrm{~g} / \mathrm{kg}$ BK) menyebabkan penurunan dalam konsumsi pakan, tetapi pertambahan berat badannya meningkat. Demikian juga Montossi et al. (1996) melaporkan bahwa terjadi peningkatan dalam pertambahan berat badan bila domba digembalakan pada hijauan Holcus lanatus (kandungan tanin kondensasi 4,2 g/kg BK). Dari bukti tersebut diduga bahwa kandungan tanin dalam hijauan leguminosa sangat berpengaruh terhadap tingkat degradasi protein ransum.

Efisiensi penggunaan ransum akibat suplementasi tepung ikan yang diproteksi dengan ekstrak tanin ketiga hijauan dalam ransum ternak kambing, tidak nyata pengaruhnya. Artinya pertambahan berat badan yang dihasilkan ternak kambing seimbang dengan pakan yang dikonsumsinya. Konsumsi bahan kering ransum dalam penelitian ini tidak 
menunjukkan pengaruh nyata akibat suplementasi tepung ikan yang diproteksi ekstrak tanin ketiga hijauan sehingga efisiensi ransum juga tidak terpengaruh. Hasil yang diperoleh dalam penelitian ini sama dengan yang dilaporkan Yulistiani, $d k k$. (2011) pada ransum domba yang disuplementasi bungkil kedelai terproteksi tanin cairan batang pisang.

\section{KESIMPULAN DAN SARAN}

\section{Kesimpulan}

1. Suplementasi tepung ikan terproteksi ekstrak tanin kabesak kuning, kabesak hitam dan kihujan berefek positip terhadap pertumbuhan ternak kambing

2. Suplementasi tepung ikan yang terproteksi ekstrak tanin kabesak kuning dan kabesak hitam dalam ransum memberikan dampak tertinggi bagi pertumbuhan ternak kambing.

\section{Saran}

1. Suplementasi tepung ikan terproteksi ekstrak tanin hijauan kabesak kuning dan atau kabesak hitam dalam ransum kambing sebesar 2\% dianjurkan untuk digunakan untuk meningkatkan pertumbuhan menjadi lebih baik.

2. Diperlukan penelitian lebih intensif suplementasi tepung ikan dengan ekstrak tanin kabesak kuning dan atau kabesak hitam dikombinasikan dengan pakan konsentrat lain yang berfungsi sebagai sumber nutrien bagi mikroba rumen untuk memacu pertumbuhan kambing menjadi optimal.

\section{DAFTAR PUSTAKA}

Aletor, V.A. 1993. Allelochemicals in plant food and feeding stuff: Nutritional, Biochemical and Physiopathological aspects in animal production. Vet. Human. Toxicol. 35 (1) : 57- 67.

Bate-Smith, E.C. 1973. Haemanalisis of tannin: The concepts of relative astringency. Phitocmestry 12:907912.

Doyle, P.T. 1990. Supplementation of Rice Straw with Dry Leucaena. School of Agriculture and Forestry, University of Melbourne, Parkville, 3052, Victoria, Australia.

El-Wazry, A.M., MEA. Nasser, and S.M.A. Salam. 2005. Processing methods of soybean meal : 1effect of roasting and tannic acids treated-soybean meal on gas production and rumen fermentation in vitro. $\mathrm{J}$ of Appl Sci Res., 1 (3) : 313-320. 
Hagerman, A.E. and C.T. Robbins. 1993. Specificity of tannin - binding salivary proteins relative to dieselection by mammals. Canadian Journal of Zoology 71 : 628-633.

Hagerman, A.E., C.T. Robbins, Y. Weerasuriya, T.C. Wilson, and C. McArthur.1992. Tanin chemistry in relation to digestion. J. Range Manage 45, 57-62.

Henson, J.E., J.S. David, and A.M. Harouna. 1997. Lactational evaluation of protein supplements of varying ruminal degradabilities. J Dairy Sci. 80 : 385 - 392 .

Huhtanen, P, and A.N. Hristov. 2009. A meta-Analysis of the effect of dietary protein concentration and degradability on milk protein yield and milk $\mathrm{N}$ efficiency in dairy cow. J. Dairy Sci. 92 (7) : $3222-3232$.

Mahadevan, S., J.D. Erfle, and S.D. Sauer. 1980. Degradation of soluble and insoluble protein by Bacteroides amylophylus protease and by rumen microorganisms. J. Anim. Sci. $50: 723$.

Miller, E.L. 1973. Evaluation of foods as source of nitrogen and amino acids. Nutr. Soc. $32: 79$.

Montossi, F.M., J. Hodgson, S.T. Morris, and D.F. Risso. 1996. Effects of the condensed tannins on animal performance in lambs grazing Yorkshire fog (Holcus lanatus) and annual rygrass (Lolium multiflorum) dominants swards.
Proc. N Z Soc Anim Prod 56, 118-121.

Saricicek, B.Z.2000. Protected (by-pass) ptotein and feed value of hazelnut kernel oil meal. Asian-Aust. J. Anim. Sci. 1 : 317-322

Steel, R.G.D. dan J.H. Torrie. 1991. Prinsip dan Prosedur Statistika Suatu Pendekatan Biometrik. PT. Gramedia Pustaka Utama, Jakarta.

Wang, Y., G.B. Douglas, G.C. Waghorn, T.N. Barry, and A.G. Foote. 1996a. Effect of condensed tannins in Lotus corniculatus upon lactation performance in ewes. J.Agric.Sci. 126: 353-362.

Wie Lawa, E.D. dan E.J.L. Lazarus. 2009. Penggunaan Ekstrak Tanin Daun Kabesak Hitam (Acacia catechu), Kabesak Kuning (Acacia leucophloea) dan Kihujan (Sammanea samman) sebagai Pelindung Protein Tepung Ikan dan Tepung Kedelai dari Degradasi Rumen. Laporan Penelitian Fundamental. Fakultas Peternakan, Universitas Nusa Cendana, Kupang.

Yulistiani, Dwi., I.W. Mathius dan W. Puastuti. 2011. Bungkil Kedelai Terproteksi Tanin Cairan Batang Pisang dalam Pakan Domba Sedang Tumbuh. JITV Vol. 16 No. 1 : 33- 40.

Yates, N.G. 1983. The effect of a salt and trace element supplement on the growth of Javanese sheep offered Leucaena leucocephala. Tropical Anim Prod. 50 - 52. 